\title{
THE REPRESENTATIVE ISSUES IN FAMILY AND LEGAL RELATIONS UNDER THE LEGISLATION OF THE REPUBLIC OF UZBEKISTAN
}

\author{
Jumagul Anvarovna Dadaboeva \\ Candidate of Legal Sciences, \\ Associate Professor, \\ Head of the Personnel Department of Ferghana State University, \\ Fergana Region, \\ Republic of Uzbekistan
}

Article DOI: https://doi.org/10.36713/epra6347

\begin{abstract}
The article analyzes the issues of representation in family law relations under the legislation of the Republic of Uzbekistan with the help of scientific literature and normative legal acts. The study also highlights the implementation of a number of social, economic and legal reforms in Uzbekistan aimed at further strengthening the family and creating a system of consistent legal regulation of family relations

KEY WORDS: Republic of Uzbekistan, legislation, legal reform, family law, representation, law, family law.
\end{abstract}

\section{INTRODUCTION}

In the following years, the attention and importance to the family increased, and the family began to be seen as the backbone of society and the state. Uzbekistan has implemented a number of social, economic and legal reforms aimed at further strengthening the family and creating a system of consistent legal regulation of family relations. It should be noted that the institution of representation has a special place in family and legal relations. The institute is currently interrelated with civil-law and civil-procedural-legal representation, and in many places, representation in the above two areas is given less attention due to special attention. However, family and legal representation in relation to minors and incapacitated children are legal representatives: parents, guardians and trustees, the adoptive parent and the elderly or incapacitated or incapacitated parent, their children in relation to the adoptive parent, the adoptive parents and differs from civillaw and civil-procedural-legal representation in terms of family-legal and kinship relationship of the representative and the person under representation. This, in turn, requires a separate study of the existing representation in the field of family law and the study of the regulation of the relationship between the representative and the person represented in terms of family law methods.

\section{METHODS}

At the same time, there are problems with the practical application of representation in family law relations, including a clearer definition of the rights and obligations of representatives, the establishment of basic criteria governing the relationship between the representative and the person represented, improvement of existing legislation, solving existing problems in law enforcement is relevant. Analysis of the representation of a parent, guardian and trustee, adoptive parent as a type of representation in familylegal relations, the application of contractual representation in family-legal relations (for example, representation of a child on behalf of his parents by power of attorney) important from the point of view.

\section{RESULTS AND DISCUSSIONS}

Article 43 of the Constitution of the Republic of Uzbekistan states that the rights and freedoms of individuals are guaranteed by the state, that is, one of the main tasks of our legislation is to protect the rights and freedoms of individuals, to ensure their inviolability. Civil law also recognizes the protection of the subjective rights and interests of individuals, their equality in civil law relations and their free movement without hindrance in the exercise of their rights, as well as the legal capacity of all persons 
regardless of their status. and if they are unable to exercise their rights on their own for objective reasons, they may exercise those rights through other persons, that is, through their own representatives. Indeed, the role and importance of civil law, especially the institution of representation in it, is great today in the protection of the rights and freedoms of individuals in our society and their unimpeded implementation. Because the institute of representation performs the following important functions:

- Ensures the timely implementation of the rights and obligations of the subjects;

- Assists individuals in exercising their rights and obligations;

- Prevents violations of legal rights and freedoms of individuals;

-Important for the development of society by ensuring the stability of legal relations between the subjects and the performance of other tasks.

Representation has developed in a certain way throughout all periods of human development, especially in ancient Egypt, China, Greece and Rome, where it was widely used in trade and handicrafts. In ancient Rome, a contract of assignment consisted of one party (mandating) giving an assignment and the other party assigning the assignment. Both legal actions and factual services are recognized as the subject of the assignment [1, p.245]. Representation was later considerably improved by the eighteenth and nineteenth centuries, and in the meantime, with some changes from the past, was legally brought to its present form. The word "representation" is a relationship in which one person acts on behalf of another person on the basis of the existing power, by directly creating (changing, terminating) rights for $\operatorname{him}[2$, p.784]. Legal encyclopedias define representation as follows: representation is the performance of an agreement and other legal actions by one person - the representative by another person - on behalf of the principal and in his interests, within its competence [3].

Thus, in accordance with Article 129 of the Civil Code of the Republic of Uzbekistan, an agreement concluded by one person (representative) on behalf of another person (representative) with a power of attorney based on a power of attorney, law, court decision or document of the authorized state body directly affects the civil rights and obligations. create, modify and cancel. If we analyze the views of scientists on the concept of representation, we can see that they are in almost the same position. For example, IB Zakirov states that representation is the performance of legal actions by one person on behalf of another person [4, p.173]. Some legal literature, on the other hand, states that representation is a legal relationship that binds a representative to an authorized person [5, p.345]. Some scholars have argued in their works that representation is a form of realization of civil legal relations [6, p.61]. In turn, a number of Russian scholars have commented on the concept of representation, including, according to A.P. Sergeeva and Yu.K. Tolstoy, that representation is the authority of a person, ie a transaction and other legal actions within the powers granted to him by the representative. is understood to be done on behalf of the employer and in its interests [7, pp.322-323]. L.Yu. Grudtsyna and A.A. Spectors, on the other hand, say that "representation is a legal relationship in which one person performs legal acts on behalf of another, that is, concludes transactions on behalf of the principal on the basis of a power of attorney, law or documents of a state body or local selfgovernment; creation, modification and termination of obligations"[8, p.222].

Another Russian civil scientist, According to M.F. Lukyanenko, representation is different from a relationship in which one person replaces another or pursues his or her own interests. Execution of legal actions is an independent will, which represents legal actions that do not repeat the will of the principal [9, p.182]. Some scholars, on the other hand, focus on the essence of representation in their works, noting that it manifests itself in the imposition of obligations on the representative to perform legal actions and conclude one or more agreements in favor of the principal [10, p.203]. Thus, representation is an action of a representative on a legal basis in the interests of the principal, aimed at the direct creation, modification and termination of civil rights and obligations in relation to him.

It is known that legal representation in family law is a type of representation in which the relationship with representation occurs in cases specified in the law on direct grounds. One of the main differences of legal representation from other types of representation is that the will of the principal is not required for its occurrence. Because he is considered incompetent. Legal representatives therefore have the right to represent the interests of the persons they represent in all relations with third parties, including in court, without a power of attorney. grounds;

-Legal representation occurs on the following

- Based on the fact of parenthood;

- In accordance with the decision of the court to determine the adoption.

- Guardianship and trusteeship based on the decision of the appointing governor.

Parents are the legal representatives of their children and protect their rights and interests in any relationship with any natural or legal person, including without special authority in court. It is enough to show the child's birth certificate or passport, as it is clear that the child is the real father or mother. According to Otahojaev, the state does not 
interfere in the process of giving parents broad rights over their children, as a general rule. However, the state sets its own conditions. The main focus is that parental rights cannot be exercised in a manner contrary to the best interests of the children [11]. Of course, parental rights are one of the highest and most inviolable rights of citizens, and deprivation of this right is the last resort. This measure applies only to those who grossly violate parental rights and responsibilities. This is a very serious loss for parents.

The current law stipulates that in the exercise of parental rights, parents must not harm the physical and mental health and moral development of children, and must refrain from disregarding the methods of raising children, cruelty, rudeness, degrading treatment, insulting or harassing children. shown. If parents exercise their parental rights against the rights and interests of children, they can be held civilly, criminally and administratively liable. According to Yuldasheva, parental responsibility can also arise on the basis of the norms of family law, that is, the existence of certain conditions can be a basis for deprivation of parental rights [13]. Of course, as a result of various objective and subjective factors that occur in life, not all parents may always be able to exercise parental rights over their children. That is, if a parent dies, is deprived of parental rights, their parental rights are restricted, they are found incompetent, ill, for a long time, the parent refuses to raise children or protect their rights and interests Guardianship and trusteeship authorities are responsible for the protection of the rights and interests of children, including when a parent refuses to take a child in educational, medical, social protection and other similar institutions, as well as in other cases deprived of parental care. This is because one of the most important tasks of guardianship and trusteeship bodies is to identify and protect the rights of children left without parental care.

According to Article 151 of the Family Code of the Republic of Uzbekistan, adoption is allowed only in respect of minors and in their interests.

Adoption is carried out on the basis of the application of the persons wishing to adopt the child and on the recommendation of the guardianship and trusteeship authority by a court decision.

Adult male or female citizens may be adoptive parents, except for the following persons:

- deprived of parental rights or have limited parental rights;

- declared incapable or with limited legal capacity in the manner prescribed by law;

- Registered in neurological or narcological institutions;

- former adoptive parents whose adoption has been annulled on the grounds specified in the first part of Article 169 of this Code;

- previously convicted for intentional crimes.
The age difference between the adopter and the adoptive parents must not be less than fifteen years, except in cases of adoption by the stepfather and stepmother.

The date of adoption is the date on which the necessary changes are made to the birth register of the adopted child. From that moment on, the adoptee, as the legal representative of the adopted child, may take various legal actions in his interests. Of course, the existence of such norms in the legislation emphasizes the importance of educating the younger generation in our country, ensuring that children are brought up in a healthy family and become fullfledged people as worthy owners of tomorrow.

Another form of legal representation currently in practice is representation appointed by a court to permanently manage the property of a citizen who has been declared missing. Of course, today, as a result of the development of entrepreneurship and a broad focus on private property, citizens are the owners of large enterprises and factories, a variety of securities. In this case, if a citizen is found to be missing, the management of his property can not be carried out through the usual institution of guardianship, in which case the court finds the citizen missing and appoints a trustee for his property [14, pp.102-103]. However, a court-appointed representative to manage the property of the missing person and to take legal action against him shall fully comply with the instructions given by the court, even if he is acting on the basis of free expression of his will.

Hence, the legislation appoints a representative to manage the property of the missing person in order to protect his property rights. But another important condition is left out of the law, i.e. the person falls into a state of coma or lethargic sleep (lying unconscious for a long time). The current legislation does not develop a mechanism to protect the rights and interests of such persons, to ensure the fulfillment of their obligations, to protect their personal non-property and property rights. However, we do not consider the condition of adults who are in a coma or lethargic sleep (prolonged unconsciousness) due to mental illness or inability to exercise their rights and obligations independently due to ill health. cannot be compared with, because if a person who is found to be incapacitated is psychologically ill, a person who is incapacitated as a sponsor because of his ill health understands everything in his place of consciousness and consciousness. According to Matkurbanov, there are a number of uncertainties in the practice of regulating the rights and interests of persons in a state of coma or lethargic sleep (prolonged unconsciousness), as well as the protection of their subjective rights. It is not possible to apply the institution of finding a citizen incompetent in this situation. Because in this case it is not a mental disorder, but a state of 
anesthesia that persists for a long time. In addition, the consequences of a state of mental disorder can lead to the recovery of the person and the lifting of the "restriction" on him.

However, the state of anesthesia can be transient because it is associated with a physical condition rather than a mental disorder. In this case, in order to protect the subjective rights and interests of citizens in a coma or lethargic sleep, it is expedient to introduce the concept of "cessation of the ability of a citizen to act" $[15$, p.13]. In our opinion, it would be more correct to say "suspension of the citizen's capacity" than "suspension of the citizen's capacity", because the word "suspension" is closer to the meaning of "suspension" than "temporary", because the capacity of citizens in a coma or lethargic sleep is completely without suspension should be suspended only temporarily, until the person regains consciousness. However, medicine cannot yet say when a person in such a situation will regain consciousness, so it would be appropriate for the court to appoint a temporary representative to protect the rights of such persons.

\section{CONCLUSION}

The following conclusions can be drawn on the basis of the study of issues related to the nature, application and problems of representation in family law in the legislation of the Republic of Uzbekistan:

1. To study the concept of representation in family law relations as a separate institution of family law of the Republic of Uzbekistan and to develop a scientific definition of it. It should be noted that today in national civilization and family law there is no definition of the concept of family-legal representation. However, as a legal category, the term needs a separate scientific definition. This situation, first of all, allows to improve the mechanisms of understanding and application of family law representation as an independent branch of law separately from civil law representation.

2. Types of representation on the basis of which exist in the doctrine today: the features of the expression of legal and contractual representation in family law are revealed. In this case, the legal representation is inextricably linked with the familylegal relationship, arises in close kinship or operates with the appropriate decision of the state body, and, conversely, the prospects of the application of contractual representation in family law, which is widely used in civil law. the legal regulation of the implementation of the contractual procedure is disclosed.

3. Scientific-theoretical analysis of the relationship between representation in family law relations and representation in civil law relations and coverage of their similarities and differences. In this case, first of all, it is necessary to consider representation in family law relations as an institution of family law and to determine the limits of application of family and civil law in its application. Such differences include the fact that representation in family law is based on kinship, first of all, the right of a parent to be a representative of his child, the choice of a representative, in contrast to civil law, is based not only on the will of the principal, but also on state bodies (guardianship and trusteeship, with the participation of juvenile commissions under district authorities).

4. The fact that the current family legislation does not regulate the representation in family-legal relations on a single system and does not have rules that are common to the types of representation, their interpretation and application give rise to different approaches. Representation in family-legal relations means not only the realization of the rights and interests of minors, but also the representation of spouses in relation to each other, the application of contractual representation in family matters, and the introduction of such provisions in the Family Code.

5. The naming of 2021 in Uzbekistan as the "Year of Youth Support and Health Promotion" and the improvement of family legislation as a priority in this regard, in turn, requires the improvement of norms governing the relationship of representation in family law. In this regard, it is necessary to improve the legislation on guardianship and trusteeship, which are special types of representation in family law relations, the rules of adoption and placement of children in family upbringing, as well as the rules of contractual representation in family law.

6. In law enforcement practice, there is no separate document of a general recommendatory nature on the application of norms and rules related to representation in family law relations. Therefore, it is necessary to adopt the Decision of the Plenum of the Supreme Court of the Republic of Uzbekistan on the application of norms related to family and legal representation and to develop rules of a recommendatory nature. For this purpose, the research provides for the preparation of a draft resolution of the Plenum.

\section{REFERENCES}

1. Roman law. Edited by I. Novitskiy Bizd. 6th, stereotyped. - M., 1997.

2. Dictionary of foreign languages. - M.: 1964.

3. Legal encyclopedia. - M: - Legal center. 1995.

4. I.B.Zokirov. Civil law. Part I. Tashkent: 2006.

5. Team of authors. Commentary to the Civil Code of the Republic of Uzbekistan Volume I.Tashkent: Vector-press, 2010.-p 345.

6. Zh. Utegenov. E Tilevov. $R$. Esbergenov. Karakalpak explanatory dictionary of legal terms..Nukus .: 2003.

7. A.P. Sergeeva., Yu.K. Tolstoy. Civil law, Textbook, Moscow, 2005.

8. 8.L.Yu. Grudtsina., A.A. Spektor. Handbook on the civil law of yielding. Phoenix. 2007. 
9. M.F. Lukyanenko. Civil law of the Russian Federation. General part: Tutorial. 2nd ed.; revised and supplemented. -Tyumen: Publishing House of Tyumen State University. 2004.

10. The article-by-article commentary on the civil code of the Russian Federation. Parts of the first, second, third. / Ed. T.E. Abova., M.M. Boguslavsky., A.Yu. Kabalkina., A.G. LisitsynaSvetlanova; Institute of State and Law of the Russian Academy of Sciences - M .: Yurayt Publishing House, 2008.

11. Otakhujaev.F. Family law of the Republic of Uzbekistan.-Tashkent, 2005.

12. Solieva.S.K. Civil legal status of minors. Dissertation abstract for the degree PhD in Law. -Tashkent, 2012.

13. Yuldasheva.Sh. Family law.-Tashkent, 2009.

14. Topildiev B.R. Civil law regulation of trust management of property. Dissertation abstract for the degree PhD in Law. -Tashkent, 2008.

15. Matgurbanov R.Zh. Problems of the legal personality of citizens (individuals) in civil law: Dissertation abstract for the degree Doctor of Law - Tashkent, 2008. 